\title{
Simulated in vitro hypoxic conditions from psoriatic arthritis cartilage change plasminogen activating system urokinase and serpine functionality. Reversal of antiapoptotic protection suggests common homeostatic buffering
}

\author{
Michal Nohawica ${ }^{1}$ Agnieszka Nowak-Terpilowska², Kinga Adamska³, Marzena Wyganowska-Swiatkowska \\ ${ }^{1}$ Department of Dental Surgery and Periodontology, Poznan University of Medical Sciences, Poznan, Poland \\ ${ }^{2}$ Department of Biochemistry and Biotechnology, Poznan University of Life Sciences, Poznan, Poland \\ ${ }^{3}$ Department of Dermatology and Venereology, Poznan University of Medical Sciences, Poznan, Poland
}

Adv Dermatol Allergol 2022; XXXIX (5): 944-952

DOI: https://doi.org/10.5114/ada.2022.113405

\begin{abstract}
Introduction: Rheumatoid and psoriatic arthritis are both characterised by synovial destruction associated with a higher turnover of the extracellular matrix. In both conditions, inflammatory processes create hypoxic environments which destabilise members of the plasminogen activating system.

Aim: Comparing the effect of bioactive concentrations of urokinase (UPA) and serpine (PAI-1) on cellular survival of human fibroblast-like-synoviocytes (HFLS) in rich and hypoxic growth media.

Material and methods: Monocultures of HFLS were exposed to bioactive UPA and PAI-1 concentrations in both media conditions for 24,48 and $72 \mathrm{~h}$. Cellular survival was evaluated with a cell viability assay by spectrum absorbance of formazan reduced WST-8.

Results: PAl-1 at 0.1 and $1 \mu \mathrm{g} / \mathrm{ml}$ was found to stimulate cell viability under hypoxic stress at 48 and $72 \mathrm{~h}$ of incubation, with the effect increasing from 48 to $72 \mathrm{~h}$. uPA increased cell viability in rich medium at 48 and $72 \mathrm{~h}$ of incubation between 5 and $40 \mathrm{ng} / \mathrm{l}$, but was found to reduce viability at $80 \mathrm{ng} / \mathrm{l}$ at 24 and $48 \mathrm{~h}$. PAl-1 increased cell viability in the hypoxic stress model, while high concentrations of uPA decreased cell viability in rich medium.

Conclusions: The alternative modes of function at extreme concentrations provide a novel description of PAI-1 and UPA activity based on their colocalization and mutual buffering capacity, helping to place these molecules more accurately in the context of arthritic synovial deterioration.
\end{abstract}

Key words: synoviocytes, plasminogen activation system, rheumatoid arthritis, psoriatic arthritis, urokinase plasminogen activator, plasminogen activator inhibitors.

\section{Introduction}

Destruction of joints is the main symptom of rheumatoid arthritis (RA). A possible explanation of this process lies in aggressive attachment of synovial fibroblasts to cartilage [1], followed by a release of proteolytic enzymes such as matrix metalloproteinases and serine proteases [2-4].

Psoriatic arthritis (PsA) is a seronegative chronic inflammatory skin and joint disease. It affects metacarpophalangeal and interphalangeal joints of the hands and feet, as well as knees and ankles [5]. Scarce data exist relating the role of hypoxia to the development of PsA [6]. Hypoxia leads to the formation of reactive oxygen species which cause damage to DNA, proteins, and lipids involved in angiogenesis, cell differentiation, migration and proliferation [7].

A high expression of NOX-2 (NADPH oxidase-2) has been found in a study with 54 patients suffering from arthritis (33 with RA and 21 with PsA). A high NOX-2 expression was correlated with low synovial PO2 levels, and with a high expression of vascular endothelial growth factor (VEGF), Ang-2, factor VIII, neural cell adhesion

Address for correspondence: Prof. Marzena Wyganowska-Swiatkowska, Chair and Department of Dental Surgery and Periodontology, Poznan University of Medical Sciences, 70 Bukowska St, 60-812 Poznan, Poland, mobile: +48601883198 ,

e-mail: marzena.wyganowska@periona.pl

Received: 6.11.2021, accepted: 28.11.2021. 
molecule, and $\alpha$-smooth muscle actin. Moreover, patients treated with anti-tissue necrosis factor (TNF)- $\alpha$ agents showed a decrease in the NOX-2 expression level and an increase in synovial PO2 [8]. Low in vivo oxygen levels have been observed in the synovium of PsA patients. Hypoxia causes an increase of urokinase plasminogen activator (UPA) stimulated release of matrix metalloproteinases (MMPs), and hypoxia-inducible factor (HIF), which in turn induces VEGF production [9].

Synovium of patients suffering from rheumatoid arthritis has a significantly higher expression of components of the plasminogen activation system (PAS) compared with non-arthritic synovium, or from patients with osteoarthritis [10].

The PAS is a proteolytic array of free and membrane bound proteins [11], which modulate the cellular response in terms of mobility, proliferation, viability, and phenotype. Directly, it is responsible for degrading extracellular matrix (ECM) protein [12].

The key protease of PAS is plasmin [13], which is activated through cleavage of plasminogen by UPA in cooperation with the urokinase plasminogen activator receptor (UPAR) [14]. UPA is released from intracellular storage by exposure to cytokines $[10,15]$ and serum molecules such as interferon $\gamma$ [16], fibronectin [17], transforming growth factor- $\beta 1$ [18], and HIF [19] as well as other inflammatory mediators [20, 21]. UPA release and plasminogen conversion activates the proteolytic processes necessary to resolve the source of inflammation [22], trauma [23], or autoimmune fibrosis [24] by stimulating cellular migration [25], proliferation [26], extracellular remodelling [27] and angiogenesis [28]. The effectiveness of UPA is strongly regulated by plasminogen activator inhibitors (PAI-1, PAI-2) and nexin [29]. In brief, UPA and PAI-1 are responsible for modulating the PAS in response to tissue damage under inflammatory, traumatic or autoimmune stimuli [30].

Recently there have been multiple reports that in RA [31] as well as in breast cancer [32] it is the co-expression of PAI-1 with UPA, which has been found to enhance angiogenesis, cellular mobility, invasiveness and excessive ECM turnover. PsA lesions also exhibit increased angiogenesis due to PAI-1 binding to UPA and cell adhesion molecules [33].

Physiological activation of PAS could encourage dedifferentiation under hypoxic [34, 35] and physical stressors $[36,37]$. Dedifferentiation is also present with UPA/PAI-1 upregulation in RA [38] and ovarian cancer [39]. PAS functions are also important for growth and development embryologically [40], however are not necessary for survival [41] and come more strongly into play during injury [42]. The adipose tissue is thought to be an adipokine reservoir, which can locally maintain the effects of PsA lesion development [43]. In our previous work the adipocyte response to PAI-1 and UPA co-stimulation has been shown to be pro-angiogenic through a concentration dependent mechanism reacting to hypoxia [44].

\section{Aim}

Growth medium starvation and the associated oxygen stress can stimulate human fibroblasts like synoviocytes (HFLS) to switch to heavy catabolic metabolism [45] and low-density lipoprotein (LDL) production [46]. Notably LDL receptor-related protein is crucial for mediating PAI-1 induced cellular migration [47], as it is yet another membrane bound target for PAI-1 colocalization [48].

Reports suggest that a non-catalytic colocalization of UPA to UPAR is sufficient [49-54] for mediation of the UPA associated angiogenesis, proliferation, and mobility seen in arthritic damage. Alternatively UPA needs to colocalise to UPAR and LDR in order to exert these effects [55]. Since colocalization of UPAR to LDR is mediated via PAI-1 [56], we aim to prove that UPA and PAI-1 have an optimum concentration for exerting these effects, and suggest they are each limited by the other when the baseline production is affected by the environmental conditions such as inflammation induced hypoxia.

\section{Material and methods}

\section{Cell culture}

HFLS were obtained from ScienCell Research Laboratories (Carlsbad, USA). Cells were cultured in Dulbecco's Modified Eagle's Medium (DMEM; Sigma-Aldrich, Poland), supplemented with 10\% Foetal Bovine Serum (FBS) and an antibiotic-antimycotic mixture (penicillin, streptomycin and amphotericin) to $1 \%$ concentration, on $25 \mathrm{~cm} 2$ plates at $37^{\circ} \mathrm{C}$ and $5 \% \mathrm{CO}_{2}$. Passaged by washing with Hank's Balanced Salt solution followed by $0.25 \%$ trypsin in $0.53 \mathrm{mM}$ EDTA. After 10 min incubation cells were mechanically detached by striking against the workbench, following which $8 \mathrm{ml}$ of culture medium was used to wash the cells and distribute across two new plates. The medium was changed every 2-3 days until 80\% confluence. Cells were saved to library in liquid nitrogen by suspending in 10\% DMSO.

\section{UPA, PAI-1, rich and hypoxic medium exposure}

Test cultures of HFLS were grown to $80 \%$ confluence on small culture flasks in $4 \mathrm{ml}$ growth medium. Passaged to 96 well plates and normalised for $24 \mathrm{~h}$ in standard cell culture medium, the cells were subsequently exposed to test media with human recombinant UPA (5, 20, 40 and $80 \mu \mathrm{g} / \mathrm{ml})$ and PAl-1 (0.1, 1 and $5 \mathrm{\mu g} / \mathrm{ml}$ ) (ProSpec-Tany TechnoGene Ltd., Israel) at both rich (10\% FBS) and the hypoxic model (0.1\% FBS) culture medium for 24, 48 and 72 h. UPA and PAI-1 concentrations were chosen for bioactive levels both under physiological and pathological processes (74-79), as no data for bioactive concentrations in vivo vs. in vitro were available.

\section{Cell viability assay}

Cell Counting Kit-8 (CCK8; Sigma-Aldrich) was used to assess the effect of test media on HFLS survival. The protocol calls for $10 \mu \mathrm{l}$ CCK-8 reagent in each tested well 
of 96 plates, followed by $1 \mathrm{~h}$ incubation at $37^{\circ} \mathrm{C}$. A series of blank calibration wells with no growth medium or cells was used for measurement control. Viability was measured by absorption of $450 \mathrm{~nm}$ wavelength light by formazan reduced WST-8. Wavelength generation and absorption measurement was carried out with Infinite M200 PRO (TECAN, Switzerland). Formazan is sensitive to necrosis induced leakage of lactate dehydrogenase [57].

\section{Statistical analysis}

Data across runs were pooled. 24,48 and $72 \mathrm{~h}$ of incubation were labelled 1, 2 and 3 days of incubation, respectively, for clarity. Means, standard deviations (SD), as well as standard error of means (SEM) were calculated for each test condition. Means were plotted on bar graphs, and SEMs were used for positive and negative errors. Regression models were made for each tested growth medium mixture and analysed using two factor ANOVA for all sample groups to assess variance between rates of change in viability, as well as one way ANOVA for effects within each sample group across all concentrations of PAS components and subsequently all durations of incubation. Post-hoc significance was assessed using two tailed equal variance $t$-tests for all significant ANOVA sample groups. $\alpha=0.05$ - LibreOffice Calc statistical package was used.

\section{Results}

\section{Control conditions}

Significant variation was found for cell viability between the control media across all days of incubation $F(2,4)=88.02, p=0.0005$. Incubation in rich control me$\operatorname{dium}(M=0.55, S D=0.06)$ resulted in significantly higher viability than in hypoxic medium $(M=0.17, S D=0.03)$ $\mathrm{t}(2)=7.6, p=0.018$, or blank $(M=0.12, \mathrm{SD}=0.02) \mathrm{t}(2)=$

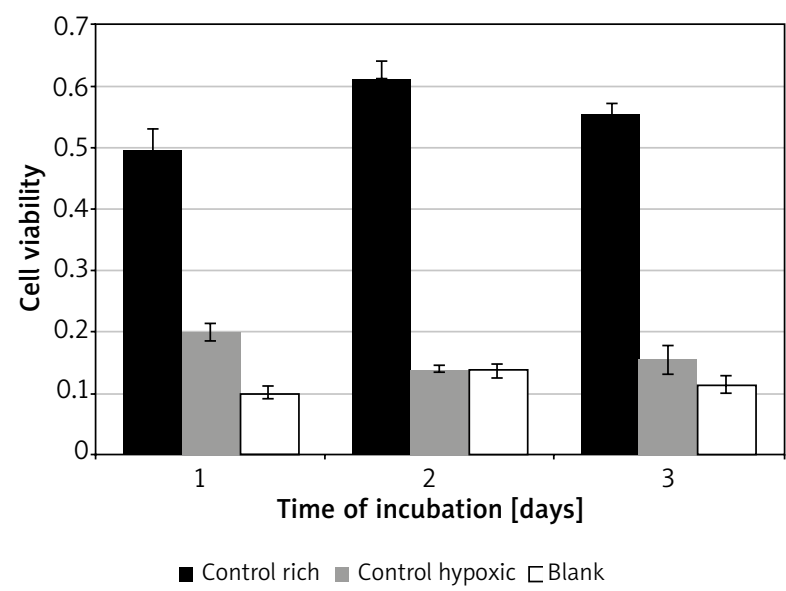

Figure 1. HFLS viability under control conditions. Control rich is $10 \%$ FBS, hypoxic is $0.1 \%$ FBS growth media and blank is cell and medium free
$18.3, p=0.003$ (Figure 1). Time of incubation had a significant effect on cell viability for the hypoxic medium only. Incubation in hypoxic medium at $24 \mathrm{~h}(\mathrm{M}=0.19, \mathrm{SD}=$ $0.04)$ resulted in significantly higher viability than at $48 \mathrm{~h}$ $(M=0.14, \mathrm{SD}=0.01) \mathrm{t}(3)=9.7, p=0.002$, or $72 \mathrm{~h}(\mathrm{M}=$ $0.15, \mathrm{SD}=0.05) \mathrm{t}(3)=4.5, p=0.02$.

\section{PAI-1 in rich medium}

Figure 2 - No significant variance, similar results across all tested concentrations and the control medium.

\section{PAI-1 in poor medium}

Incubation on day 2 in hypoxic medium ( $M=0.14$, SD $=0.01)$ resulted in significantly lower cell viability than in PAl-1 at $0.1 \mu \mathrm{g} / \mathrm{ml}(\mathrm{M}=0.32, \mathrm{SD}=0.02) \mathrm{t}(2)=31.1$, $p=0.001,1 \mu \mathrm{g} / \mathrm{ml}(\mathrm{M}=0.31, \mathrm{SD}=0.02) \mathrm{t}(3)=25.8$, $p=0.0001$ or $5 \mathrm{\mu g} / \mathrm{mlt}(3)=18.80, p=0.0003$ (Figure 3). Incubation on day 2 in PAl-1 $0.1 \mu \mathrm{g} / \mathrm{ml}(\mathrm{M}=0.32$, $\mathrm{SD}=0.02)$ also resulted in significantly higher cell viability than at $5 \mu \mathrm{g} / \mathrm{ml} \mathrm{t}(2)=7.39, p=0.019$.

\section{PAl-1 in hypoxic medium}

Incubation on day 1 in UPA at $20 \mathrm{ng} / \mathrm{ml}(\mathrm{M}=0.79$, SD $=0.12$ ) resulted in significantly higher cell viability than in rich control medium $(M=0.32, S D=0.02) \mathrm{t}(3)=15.5$, $p=0.0006$, or in UPA at $5 \mathrm{ng} / \mathrm{ml}(\mathrm{M}=0.52, \mathrm{SD}=0.07)$ $\mathrm{t}(3)=4.49, p=0.02$ and $80 \mathrm{ng} / \mathrm{ml}(\mathrm{M}=0.37, \mathrm{SD}=0.08)$ $\mathrm{t}(3)=4.46, p=0.021$ (Figure 4).

Incubation on day 2 in UPA at $80 \mathrm{ng} / \mathrm{ml}(\mathrm{M}=0.45$, SD $=0.09$ ) resulted in significantly lower cell viability than in rich control medium $(M=0.61, \mathrm{SD}=0.06) \mathrm{t}(3)=3.21$, $p=0.049$, or in UPA at $5 \mathrm{ng} / \mathrm{ml}(\mathrm{M}=0.80, \mathrm{SD}=0.08)$ $\mathrm{t}(3)=5.27, p=0.013$ and $40 \mathrm{ng} / \mathrm{ml}(\mathrm{M}=0.81, \mathrm{SD}=0.13)$ $\mathrm{t}(3)=6.83, p=0.006$

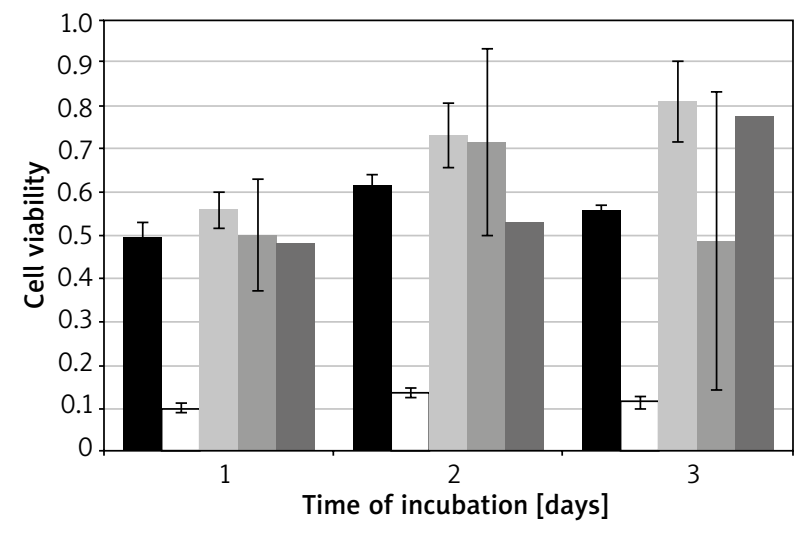

- Control rich $\square$ Blank $\square$ PAl-1 $0.1 \mu$ grich $\square$ PAI-1 $1 \mu \mathrm{g}$ rich $\square$ PAl-1 $5 \mu \mathrm{g}$ rich

Figure 2. HFLS viability under PAI-1 concentrations in rich growth medium 


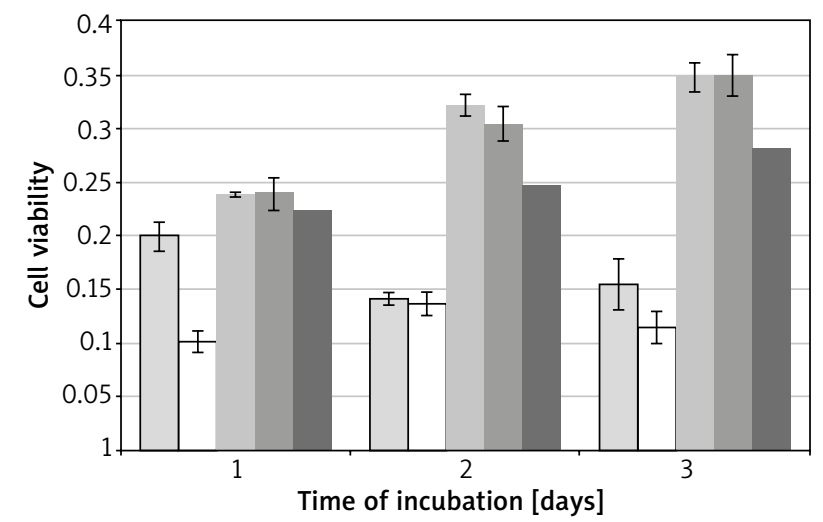

$\square$ Control hypoxic $\square$ Blank $\square$ PAl-1 $0.1 \mu \mathrm{g}$ hypoxic $\square$ PAl-1 $1 \mu \mathrm{g}$ hypoxic - PAl-1 $5 \mu \mathrm{g}$ hypoxic

Figure 3. HFLS viability under PAI-1 concentrations in hypoxic growth medium

Incubation on day 3 in rich control medium $(M=0.56$, $\mathrm{SD}=0.03)$ resulted in significantly lower cell viability than in UPA at $5 \mathrm{ng} / \mathrm{ml}(\mathrm{M}=0.81, \mathrm{SD}=0.05) \mathrm{t}(3)=20.64$, $p=0.0002$, and $40 \mathrm{ng} / \mathrm{ml}(\mathrm{M}=0.79, \mathrm{SD}=0.09) \mathrm{t}(3)=$ $3.79, p=0.032$.

Incubation in UPA at $5 \mathrm{ng} / \mathrm{ml}$ for 1 day $(M=0.52, \mathrm{SD}$ $=0.07)$ resulted in significantly lower cell viability than for 2 days $(M=0.80, S D=0.077) t(3)=6.05, p=0.009$ or 3 days $(M=0.81, \mathrm{SD}=0.052) \mathrm{t}(3)=7.05, p=0.006$.

\section{UPA in hypoxic medium}

Incubation on day 2 in hypoxic medium $(M=0.14$, SD $=0.01)$ resulted in significantly lower cell viability than in uPA at $5 \mathrm{ng} / \mathrm{ml}(\mathrm{M}=0.21, \mathrm{SD}=0.0086) \mathrm{t}(3)=12.08, p=$ $0.001,20 \mathrm{ng} / \mathrm{ml}(\mathrm{M}=0.21, \mathrm{SD}=0.026) \mathrm{t}(3)=5.97, p=$ $0.009,40 \mathrm{ng} / \mathrm{ml}(\mathrm{M}=0.21, \mathrm{SD}=0.015) \mathrm{t}(3)=20.22, p=$ 0.0003 , and $80 \mathrm{ng} / \mathrm{ml}(\mathrm{M}=0.18, \mathrm{SD}=0.024) \mathrm{t}(3)=6.08$, $p=0.009$.

Incubation on day 2 in UPA at $40 \mathrm{ng} / \mathrm{ml}$ resulted in significantly higher cell viability than in UPA at $80 \mathrm{ng} / \mathrm{ml}$ $\mathrm{t}(3)=4.86, p=0.017$ (Figure 5).

\section{Discussion}

Many pathological processes involve a dysregulation of PAS, such as the upregulation of plasmin activity in arthritis [58, 59] and cancer [60], or its downregulation in fibrosis [61-63]. Cancer therapies utilising PAS suggest stimulating the secretion or delivery of PAI-1, which would stop uPA mediated angiogenesis, however this approach has not brought promising results yet [64]. Connective tissue and autoimmune disorder studies suggest, however, that uPA over activation in RA can be inhibited by PAI-1 suppression $[65,66]$. In terms of pathologies which suffer from uPA downregulation, treatment by supplementation of UPA has yielded some positive re-

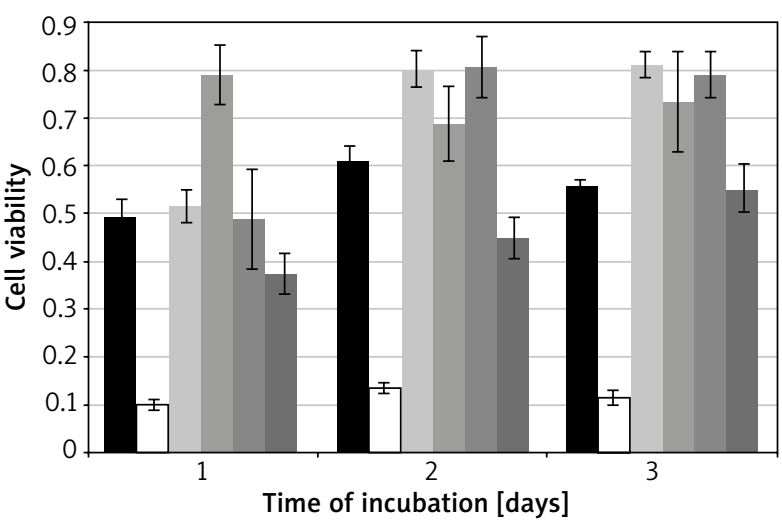

- Control rich $\square$ Blank $\square$ UPA 5 ng rich —UPA 20 ng rich — UPA 40 ng rich -UPA $80 \mathrm{ng}$ rich

Figure 4. HFLS viability under UPA concentrations in rich growth medium

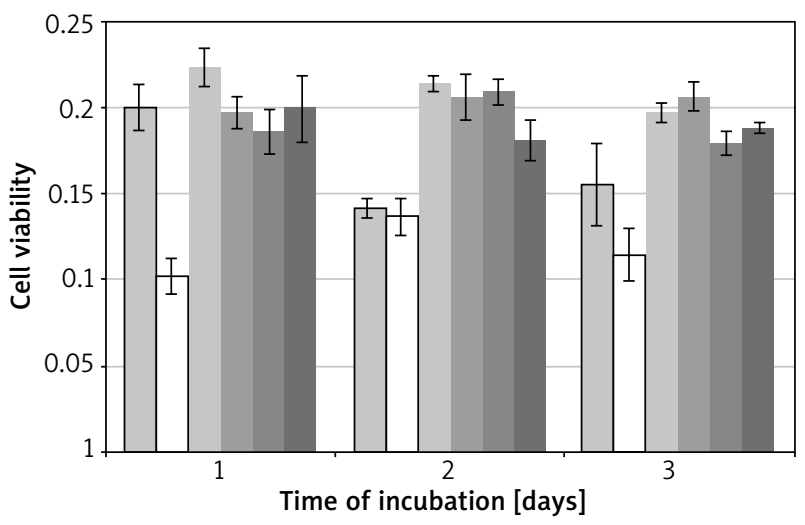

$\square$ Control hypoxic $\square$ Blank $\square$ UPA 5 ng hypoxic $\square$ PUPA 20 ng hypoxic - UPA 40 ng hypoxic U UPA 80 ng hypoxic

Figure 5. HFLS viability under UPA concentrations in hypoxic growth medium

sults in pulmonary [67] and liver [68] fibrosis models, but not in renal fibrosis [69].

Prevalence of either molecule in pathological conditions could stem from testing UPA and PAI- 1 in isolation. Their common transcription pathway - Wnt3a/ $\beta$-catenin induced release of nuclear factor $k$-light-chain-enhancer of activated B cells (NF- $\mathrm{B}$ ) [70-72] - provides further insight. Expression of the urokinase gene can be acti-

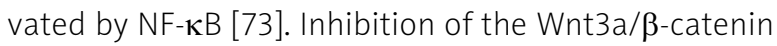
pathway has been shown to improve RA outcomes by stimulating synoviocyte apoptosis [74], while PsA associated subchondral degradation is thought to be activated by Wnt5a mediated NF- $\kappa B$ release [75]. This is thought to be due to HFLS overexpression of integrins resulting in overactivation of integrin mediated ECM binding [76], and a higher UPA mediated integrin associated prote- 
olysis and subsequent destruction of those attachments [77-79], resulting in synovial degradation.

Since integrin associated UPA targeting of ECM proteins and subsequent detachment can be mediated by colocalization of PAI-1/integrin/UPAR/UPA [80], a reduced production of PAI- 1 by the inhibited $\mathrm{Wnt} 3 \mathrm{a} / \beta$-catenin pathway could reduce the integrin mediated endocytic recycling [81], resulting in lower reformation of surface integrin attachment and therefore a detachment of the overactive synoviocytes, and their subsequent apoptosis $[82,83]$. This phenomenon is further supported by the anti-apoptotic effect PAI-1 has in other cell lines [84-86]. Even in PSA, the effect of anti-rheumatic disease modifying medications as well as more targeted TNF- $\alpha$ inhibitors seems to be heavily dependent on reducing both UPA and PAI-1 together, and not in isolation [87].

In our study we observed the influence of PAI-1 and UPA on HFLS in hypoxia induced by low concentration of nutrients in the culture medium. Incubation in medium containing high serum concentration boosts cell viability, and higher concentrations allow for better cellular adaptation [88]. Presence of nutrients and growth stimulating cytokines is key for cellular survival [89], growth, as well as attachment [76, 90]. In order to mitigate low nutrient stress, human cells cope by producing lipid droplets which initiate fatty acid catabolism [91]. Nutrient stress induced by serum starvation, such as $0.1 \%$ FBS, can prime and sensitise cells to apoptotic stimuli [92]. Hypoxia induced by the energy intensive catabolic fat metabolism is such an apoptotic stimulus [93].

In the absence of a phagocytic clearance mechanism, apoptotic cells undergo secondary necrosis releasing internal cell components [94]. These components are immunostimulatory, such as the inflammatory danger associated molecular patterns [95]. The most common systemic phagocytic clearance mechanism is scavenger cells which originate from the myeloid phagocyte system, also known as the professional phagocytes - macrophages [96], which would normally be absent in a HFLS monoculture, as it originates from the mesenchyme [97].

Secondary necrosis in vivo results in an increased inflammatory response and can lead to severely destructive pathology [98]. In vitro, activation of synoviocytes by noxious stimuli in inflammatory conditions can induce a release of latent membrane bound matrix metalloproteinases as well as serine proteases [99]. These proteases, collagenases, and ECM degrading molecules are also released from the cell membrane as a late-stage effect of secondary necrosis, further reducing the attachment of surviving local cultures which lack phagocytic clearance mechanisms. Growth arrest, nutrient depletion, apoptosis and secondary necrosis are all timed events dependent on local nutrient and oxygen availability, as well as clearance of toxic products. We have shown that for HFLS under serum starvation, the completion of these processes could take more than $24 \mathrm{~h}$.
PAI-1 is naturally secreted by synoviocytes during pathological processes such as RA [100], but also serves a physiological role in protecting the synoviocytes from inflammatory processes and modulating the UPA activity [73]. It is elevated during inflammatory processes such as diabetes [101], and reports show that it has an inhibitory function during wound healing [102]. Nonetheless, PAI-1 expression was found to be elevated in invasive breast cancer [103]. Classically PAI-1 inhibits cellular mobility and remodelling which would otherwise be caused by UPA, therefore causing fibrosis and morbidity in obesity and wound healing.

PAI-1 had a significant effect on improving cell viability in hypoxia, especially at low concentrations, with the effect increasing over time. Hypoxia is stress inducing, and the cellular response is catabolic, inflammatory followed by apoptotic and necrotic. Apoptosis is concomitant with formation of blebbing, resulting in detachment internally and externally through fibre contractions [104]. Extracellular PAI-1 could slow down this detachment by inhibiting the UPA, which is secreted in response to apoptosis and necrosis. This observation is in line with other groups finding that PAI-1 can mediate protection against efferocytosis of neutrophils [85], FasL-mediated endothelial cell apoptosis [105], and fibrosis-induced apoptosis of fibroblasts [84]. Since the protective effect is inversely proportional to concentration, suggesting an external limiting factor.

Classically PAI-1 is inhibitory to cellular mobility, survival, and extracellular remodelling. We have seen that in hypoxic conditions, where cellular processes are in a catabolic halt and the apoptotic release of UPA could stimulate ECM detachment, the role of PAI-1 can be different. At low concentrations we suggest it plays a role in disarming the surplus secreted UPA, and inhibiting the apoptotic detachment, increasing proliferation and cell viability. However, at concentrations exceeding the buffering capacity of UPA, PAI-1 would go on to act classically to decrease cell viability. The effect of PAI-1 mediated protection becomes more pronounced over the 3 days, suggesting a level of adaptation of the culture to the hypoxia inducing medium, which could be due to better attachment or, as other groups have found, due to dedifferentiation [106].

UPA is usually defined as a plasminogen activator playing a key role in cell migration, proliferation and ECM remodelling - especially during wound healing [107]. There are many reports of its involvement in pathological processes, most notably cancer, where it has been conducive $[108,109]$ to invasive phenotypes. Our data also suggest a boost in cell viability at low UPA concentrations.

However, UPA is also involved in stimulating PAI-1 mediated endocytosis [110]. Overactivation of plasmin, and MMP mediated ECM degradation, can cause cellular detachment and stress [111]. If endocytosis of the UPA/ PAI-1/uPAR complex exceeds the pace of cellular ability to 
replenish membrane stocks, cells undergo non-apoptotic death [112]. These alternative modes of interaction with the ECM can serve as an explanation for our observed drop in cell viability at high concentrations of UPA. The resolution of this decrease in viability over the 3 days of incubation could be due to the cellular recycling of excess UPA.

At high UPA concentrations, ECM degradation, proteolysis, and detachment occur too quickly, resulting in cellular stress which maintains the apoptotic state. The hypoxia induced release of uPA could explain why there was no significant difference between the control conditions and the UPA concentrations in hypoxic medium. Increased cell viability over the hypoxic medium on the second day of incubation could be explained by the catabolic hypoxic stress activating the Wnt3a/ $\beta$-catenin signalling pathway [113], which is found to be involved in apoptotic protection [114] by stimulating both UPA and PAI-1 [70] secretion in tandem, allowing both molecules to follow the classical pathway of increased mobility, proliferation and survival.

Severe and chronic diseases can exhibit overexpression of both UPA and PAI-1, such as in RA or PsA, leading to excessive tissue damage, as well as cases of high PAI-1 cancers metastasizing due to more stable angiogenesis. The localisation of PAI-1 to ECM attachment molecules could prove to be the next step in understanding these interactions. PAI- 1 binds to ECM attachment molecules together with UPA/UPAR forming a pentameric complex of UPAR/UPA/PAI-1/vitronectin, which is able to combine further with LDR. The local activation of UPA near PAI-1/ vitronectin triggers ECM detachment and UPAR/UPA/ PAI-1/vitronectin/LDR clathrin mediated internalization. Homeostatic cellular systems can then designate the clathrin contents to degradation or cell membrane recycling. Elements of this mechanism can be observed during carcinogenesis [115].

Our data suggest that UPA can induce a decrease in cell viability, which in turn could occur by stimulation of detachment and plasmin/MMP activation leading to apoptosis. We have shown that PAI-1 can stimulate cell viability in hypoxic stress conditions. The possibility of stimulating attachment and stabilisation as well as endocytosis via the UPAR/PAI-1/integrin complex, even at low extracellular PAI-1 concentrations, is a known mechanism. We further show that PAI-1 is not inhibitory to cellular proliferation in low stress conditions, while UPA does not stimulate proliferation or protect from apoptosis in hypoxic stress conditions. The inhibitory effect of UPA on cellular viability at high concentrations in rich medium can cause extracellular depletion of PAI-1 which could in turn result in UPA activated detachment and apoptosis instead of PAl-1 mediated endocytosis.

We found that in rich medium both UPA and PAI-1 have a decreasing stimulatory effect on survival with increased dosage, suggesting that outside of hypoxic stress, both of these molecules are homeostatically well regulated by the cell. The introduction of excessive amounts of either molecule overpowers the homeostatic mechanisms resulting in an inhibition of viability. We therefore conclude that the most likely mechanism of excessive, rapid, and destructive tissue turnover as present in PSA is due to the combined activity of both UPA and PAI-1, released by the cell due to the hypoxic stimuli through the activation of NF- $\mathrm{BB}$ transcription, depletion of cellular reservoirs, heightened activity of local adipose buffers due to systemic comorbidities and immune responses and homeostatically to buffer the other elements of PAS. Further research will need to focus on optimising these destructive stimuli.

\section{Acknowledgments}

Special thanks go to the Poznan University of Medical Sciences and Poznan University of Life Sciences for providing the resources to carry out this project.

The work has been carried out in a laboratory at the Department of Biochemistry and Biotechnology, Poznan University of Life Sciences, Dojazd 11, 60-632 Poznan, Poland.

\section{Conflict of interest}

The authors declare no conflict of interest.

\section{References}

1. Müller-Ladner U, Kriegsmann J, Franklin BN, et al. Synovial fibroblasts of patients with rheumatoid arthritis attach to and invade normal human cartilage when engrafted into SCID mice. Am J Pathol 1996; 149: 1607-15.

2. Hardin JG. Textbook of rheumatology. Second edition. Arthritis \& Rheumatism 1986; 29: 455.

3. Mochan E, Keler T. Plasmin degradation of cartilage proteoglycan. Biochim Biophys Acta 1984; 800: 312-5.

4. Saito S, Katoh M, Masumoto M, et al. Collagen degradation induced by the combination of IL-1alpha and plasminogen in rabbit articular cartilage explant culture. J Biochem 1997; 122: 49-54.

5. Krakowski P, Gerkowicz A, Pietrzak A et al. Psoriatic arthritis - new perspectives. Arch Med Sci 2019; 15: 580-9.

6. Ng CT, Biniecka M, Kennedy A, et al. Synovial tissue hypoxia and inflammation in vivo. Ann Rheum Dis 2010; 69: 1389-95.

7. Valko M, Izakovic M, Mazur M, et al. Role of oxygen radicals in DNA damage and cancer incidence. Mol Cell Biochem 2004; 266: 37-56.

8. Biniecka M, Connolly M, Gao W, et al. Redox-mediated angiogenesis in the hypoxic joint of inflammatory arthritis. Arthritis Rheumatol 2014; 66: 3300-10.

9. Tischer E, Mitchell R, Hartman T, et al. The human gene for vascular endothelial growth factor. Multiple protein forms are encoded through alternative exon splicing. I Biol Chem 1991; 266: 11947-54.

10. Ronday HK, Smtts HH, Van Muijen GNP, et al. Difference in expression of the plasminogen activation system in synovial 
tissue of patients with rheumatoid arthritis and osteoarthritis. Rheumatology 1996; 35: 416-23.

11. Danø K, Andreasen PA, Grøndahl-Hansen J, et al. Plasmino gen activators, tissue degradation, and cancer. Adv Cancer Res 1985; 44: 139-266.

12. Mazzieri R, Masiero L, Zanetta L, et al. Control of type IV collagenase activity by components of the urokinase-plasmin system: a regulatory mechanism with cell-bound reactants. EMBO J 1997; 16: 2319-32.

13. Castellino FJ. Biochemistry of human plasminogen. Semin Thromb Hemost 1984; 10: 18-23.

14. Choong PFM, Nadesapillai APW. Urokinase plasminogen activator system: a multifunctional role in tumor progression and metastasis. Clin Orthop Related Res 2003; 415: S46.

15. Ito A, Itoh Y, Sasaguri Y, et al. Effects of interleukin- 6 on the metabolism of connective tissue components in rheumatoid synovial fibroblasts. Arthritis Rheum 1992; 35: 1197-201.

16. Sitrin RG, Todd RF, Mizukami IF, et al. Cytokine-specific regulation of urokinase receptor (CD87) expression by U937 mononuclear phagocytes. Blood 1994; 84: 1268-75.

17. Urtreger AJ, Aguirre Ghiso JA, Werbajh SE, et al. Involvement of fibronectin in the regulation of urokinase production and binding in murine mammary tumor cells. Int J Cancer 1999; 82: 748-53.

18. Smith PC, Martínez J. Differential UPA expression by TGF- $\beta 1$ in gingival fibroblasts. J Dent Res 2006; 85: 150-5.

19. Nishi H, Sasaki T, Nagamitsu Y, et al. Hypoxia inducible factor-1 mediates upregulation of urokinase-type plasminogen activator receptor gene transcription during hypoxia in cervical cancer cells. Oncol Rep 2016; 35: 992-8.

20. Hwang HS, Kim JW, Oh SH, et al. TLR5 activation induces expression of the pro-inflammatory mediator urokinase plasminogen activator via NF- B and MAPK signalling pathways in human dental pulp cells. Int Endodontic J 2019; 52 1479-88.

21. Pérez-García S, Carrión M, Jimeno R, et al. Urokinase plasminogen activator system in synovial fibroblasts from osteoarthritis patients: modulation by inflammatory mediators and neuropeptides. J Mol Neurosci 2014; 52: 18-27.

22. Sugimoto MA, Ribeiro ALC, Costa BRC, et al. Plasmin and plasminogen induce macrophage reprogramming and regulate key steps of inflammation resolution via annexin A1. Blood 2017; 129: 2896-907.

23. Arginteanu MS, Byun H, King W. Treatment of a recurrent subdural hematoma using urokinase. J Neurotrauma 1999; 16: 1235-9

24. Ma ZG, Lv XD, Zhan LL, et al. Human urokinase-type plasminogen activator gene-modified bone marrow-derived mesenchymal stem cells attenuate liver fibrosis in rats by down-regulating the Wnt signaling pathway. World J Gas troenterol 2016; 22: 2092-103.

25. Goncharova EA, Tkachuk VA, Ratner El, et al. Role of mitogen-activated protein kinases in stimulation of smooth muscle cell migration by urokinase. J Evolutionary Biochem Physiol 2000; 36: 744-53.

26. Kirchheimer JC, Wojta J, Christ G, et al. Proliferation of a human epidermal tumor cell line stimulated by urokinase. FASEB J 1987; 1: 125-8.

27. Lu P, Takai K, Weaver VM, et al. Extracellular matrix degradation and remodeling in development and disease. Cold Spring Harb Perspect Biol 2011; 3: a005058.

28. Semina EV, Rubina KA, Sysoeva VY, et al. The role of urokinase in vascular cell migration and in regulation of growth and branching of capillaries. Cell Tiss Biol 2016; 10: 37-46.
29. Arroyo De Prada N, Schroeck F, Sinner EK, et al. Interaction of plasminogen activator inhibitor type-1 (PAI-1) with vitronectin. Eur J Biochem 2002; 269: 184-92.

30. Lin H, Xu L, Yu S, et al. Therapeutics targeting the fibrinolytic system. Exp Mol Med 2020; 52: 367-79.

31. Buckley BJ, Ali U, Kelso MJ, et al. The urokinase plasminogen activation system in rheumatoid arthritis: pathophysiological roles and prospective therapeutic targets. Curr Drug Targets 2019; 20: 970-81.

32. Singer CF, Filipits $M$, Jahn SW, et al. Stromal coexpression of UPA/PAI-1 protein predicts poor disease outcome in endocrine-treated postmenopausal patients with receptorpositive early breast cancer. Breast 2019; 46: 101-7.

33. Zdanowska N, Kasprowicz-Furmańczyk M, Placek W, et al. The role of chemokines in psoriasis - an overview. Medicina 2021; 57: 754.

34. Hosogai N, Fukuhara A, Oshima K, et al. Adipose tissue hypoxia in obesity and its impact on adipocytokine dysregulation. Diabetes 2007; 56: 901-11.

35. Park YK, Park B, Lee S, et al. Hypoxia-inducible factor-2 dependent hypoxic induction of Wnt10b expression in adipogenic cells. J Biol Chem 2013; 288: 26311-22.

36. Kiyan Y, Tkachuk S, Hilfiker-Kleiner D, et al. oxLDL induces inflammatory responses in vascular smooth muscle cells via urokinase receptor association with CD36 and TLR4. J Mol Cell Cardiol 2014; 66: 72-82.

37. Kiyan J, Kusch A, Tkachuk S, et al. Rosuvastatin regulates vascular smooth muscle cell phenotypic modulation in vascular remodeling: role for the urokinase receptor. Atherosclerosis 2007; 195: 254-61.

38. Choi HS, Ryu CJ, Choi HM, et al. Effects of the pro-inflammatory milieu on the dedifferentiation of cultured fibroblastlike synoviocytes. Mol Med Rep 2012; 5: 1023-6.

39. Borgfeldt C, Hansson SR, Gustavsson B, et al. Dedifferentiation of serous ovarian cancer from cystic to solid tumors is associated with increased expression of mRNA for urokinase plasminogen activator (UPA), its receptor (UPAR) and its inhibitor (PAI-1). Int J Cancer 2001; 92: 497-502.

40. Herz J, Clouthier DE, Hammer RE. LDL receptor-related protein internalizes and degrades UPA-PAI-1 complexes and is essential for embryo implantation. Cell 1992; 71: 411-21.

41. Carmeliet P, Kieckens L, Schoonjans L, et al. Plasminogen activator inhibitor-1 gene-deficient mice. I. Generation by homologous recombination and characterization. J Clin Invest 1993; 92: 2746-55.

42. Popa NL, Wergedal JE, Lau KHW, et al. Urokinase plasminogen activator gene deficiency inhibits fracture cartilage remodeling. J Bone Miner Metab 2014; 32: 124-35.

43. Russolillo A, lervolino S, Peluso R, et al. Obesity and psoriatic arthritis: from pathogenesis to clinical outcome and management. Rheumatology 2013; 52: 62-7.

44. Nohawica M, Errachid A, Wyganowska-Swiatkowska M. Adipose-PAS interactions in the context of its localised bioengineering potential. Biomed Rep 2021; 15: 70.

45. Kaur J, Debnath J. Autophagy at the crossroads of catabolism and anabolism. Nature Rev Mol Cell Biol 2015; 16: 461-72.

46. Mollace V, Gliozzi M, Musolino V, et al. Oxidized LDL attenuates protective autophagy and induces apoptotic cell death of endothelial cells: role of oxidative stress and LOX-1 receptor expression. Int J Cardiol 2015; 184: 152-8.

47. Degryse B, Neels JG, Czekay RP, et al. The low density lipoprotein receptor-related protein is a motogenic receptor for plasminogen activator inhibitor-1. J Biol Chem 2004; 279: 22595-604. 
48. Croucher DR, Saunders DN, Stillfried GE, et al. A structural basis for differential cell signalling by PAI-1 and PAI-2 in breast cancer cells. Biochem J 2007; 408: 203-10.

49. Stoppelli MP. The Plasminogen Activation System in Cell Invasion. Landes Biosciences, Austin (TX). 2013.

50. Tkachuk V, Stepanova V, Little PJ, et al. Regulation and role of urokinase plasminogen activator in vascular remodelling. Clin Exp Pharmacol Physiol 1996; 23: 759-65.

51. Klimovich PS, Semina EV, Karagyaur MN, et al. Urokinase receptor regulates nerve regeneration through its interaction with $\alpha 5 \beta 1$-integrin. Biomed Pharmacother 2020; 125 : 110008.

52. Whyte CS, Mutch NJ. UPA-mediated plasminogen activation is enhanced by polyphosphate. Haematological 2021; 106 : 522-31.

53. Merino P, Diaz A, Jeanneret $V$, et al. Urokinase-type plasminogen activator (UPA) binding to the UPA receptor (UPAR) promotes axonal regeneration in the central nervous system. J Biol Chem 2017; 292: 2741-53.

54. Smith HW, Marshall CJ. Regulation of cell signalling by UPAR. Nat Rev Mol Cell Biol 2010; 11: 23-36.

55. Czekay RP, Kuemmel TA, Orlando RA, et al. Direct binding of occupied urokinase receptor (UPAR) to LDL receptor-related protein is required for endocytosis of UPAR and regulation of cell surface urokinase activity. Mol Biol Cell 2001; 12: 1467-79.

56. Binder BR, Mihaly J, Prager GW. UPAR - UPA - PAI-1 interactions and signaling: a vascular biologist's view. Thromb Haemost 2007; 97: 336-42.

57. Chan FKM, Moriwaki K, Rosa MJD. Detection of necrosis by release of lactate dehydrogenase (LDH) activity. Methods Molr Biol 2013; 979: 65-70.

58. Judex MO, Mueller BM. Plasminogen activation/plasmin in rheumatoid arthritis. Am J Pathol 2005; 166: 645-7.

59. Busso N, Péclat V, So A, et al. Plasminogen activation in synovial tissues: differences between normal, osteoarthritis, and rheumatoid arthritis joints. Ann Rheum Dis 1997; 56: 550-7.

60. Binder BR, Mihaly J. The plasminogen activator inhibitor "paradox" in cancer. Immunol Letters 2008; 118: 116-24.

61. Crooks MG, Hart SP. Coagulation and anticoagulation in idiopathic pulmonary fibrosis. Eur Respir Rev 2015; 24: 392-9.

62. Baricos WH, Cortez SL, Deboisblanc M, et al. Transforming growth factor-beta is a potent inhibitor of extracellular matrix degradation by cultured human mesangial cells. J Am Soc Nephrol 1999; 10: 790-5.

63. Gong R, Rifai A, Tolbert EM, et al. Hepatocyte growth factor modulates matrix metalloproteinases and plasminogen activator/plasmin proteolytic pathways in progressive renal interstitial fibrosis. J Am Soc Nephrol 2003; 14: 3047-60.

64. Li S, Wei X, He J, et al. Plasminogen activator inhibitor-1 in cancer research. Biomed Pharmacother 2018; 105: 83-94.

65. Van Ness K, Chobaz-Péclat V, Castellucci M, et al. Plasminogen activator inhibitor type-1 deficiency attenuates murine antigen-induced arthritis. Rheumatology 2002; 41: 136-41.

66. Makrilakis K, Fragiadaki K, Smith J, et al. Interrelated reduction of chemerin and plasminogen activator inhibitor-1 serum levels in rheumatoid arthritis after interleukin-6 receptor blockade. Clin Rheumatol 2015; 34: 419-27.

67. Sisson TH, Hattori N, Xu Y, et al. Treatment of bleomycin-induced pulmonary fibrosis by transfer of urokinase-type plasminogen activator genes. Hum Gene Ther 1999; 10: 2315-23.

68. Wang B, Li W, Chen Y, et al. Coexpression of Smad7 and UPA attenuates carbon tetrachloride-induced rat liver fibrosis. Med Sci Monit 2012; 18: BR394-401.
69. Zhang G, Eddy AA. Urokinase and its receptors in chronic kidney disease. Front Biosci 2008; 13: 5462-78.

70. Moreau M, Mourah S, Dosquet C. $\beta$-Catenin and NF-KB cooperate to regulate the UPA/UPAR system in cancer cells. Int J Cancer 2011; 128: 1280-92.

71. Hiendlmeyer E, Regus S, Wassermann S, et al. Beta-catenin up-regulates the expression of the urokinase plasminogen activator in human colorectal tumors. Cancer Res 2004; 64: 1209-14.

72. Pang L, Wang Y, Zheng M, et al. Transcriptomic study of highglucose effects on human skin fibroblast cells. Mol Med Rep 2016; 13: 2627-34.

73. Nagamine Y, Medcalf RL, Muńoz-Cánoves P. Transcriptional and posttranscriptional regulation of the plasminogen activator system. Thromb Haemost 2005; 93: 661-75.

74. Wu J, Fan W, Ma L, et al. miR-708-5p promotes fibroblast-like synoviocytes' cell apoptosis and ameliorates rheumatoid arthritis by the inhibition of Wnt3a/ $\beta$-catenin pathway. Drug Des Dev Ther 2018; 12: 3439-47.

75. Tian F, Mauro TM, Li Z. The pathological role of Wnt5a in psoriasis and psoriatic arthritis. I Cell Mol Med 2019; 23: 5876-83.

76. Rinaldi N, Schwarz-Eywill M, Weis D, et al. Increased expression of integrins on fibroblast-like synoviocytes from rheumatoid arthritis in vitro correlates with enhanced binding to extracellular matrix proteins. Ann Rheum Dis 1997; 56: 45-51.

77. Rocha LA, Learmonth DA, Sousa RA, et al. $\alpha \vee \beta 3$ and $\alpha 5 \beta 1$ integrin-specific ligands: From tumor angiogenesis inhibitors to vascularization promoters in regenerative medicine? Biotechnol Adv 2018; 36: 208-27.

78. Millard M, Odde S, Neamati N. Integrin targeted therapeutics. Theranostics 2011; 1: 154-88.

79. Morshed A, Abbas AB, Hu J, et al. Shedding new light on the role of $\alpha v \beta 3$ and $\alpha 5 \beta 1$ integrins in rheumatoid arthritis. Molecules 2019; 24: 1537.

80. Czekay RP, Aertgeerts K, Curriden SA, et al. Plasminogen activator inhibitor-1 detaches cells from extracellular matrices by inactivating integrins. J Cell Biol 2003; 160: 781-91.

81. Czekay RP, Wilkins-Port CE, Higgins SP, et al. PAI-1: an integrator of cell signaling and migration. 2011; 2011: 562481.

82. Erdreich-Epstein A, Tran LB, Cox ÓT, et al. Endothelial apoptosis induced by inhibition of integrins $\alpha \vee \beta 3$ and $\alpha \vee \beta 5$ involves ceramide metabolic pathways. Blood 2005; 105: 4353-61.

83. Oguey D, George PW, Rüegg C. Disruption of integrin-dependent adhesion and survival of endothelial cells by recombinant adenovirus expressing isolated $\beta$ integrin cytoplasmic domains. Gene Therapy 2000; 7: 1292-303.

84. Huang WT, Akhter H, Jiang C, et al. Plasminogen activator inhibitor 1, fibroblast apoptosis resistance, and aging-related susceptibility to lung fibrosis. Exp Gerontol 2015; 61: 62-75.

85. Park YJ, Liu G, Lorne EF, et al. PAI-1 inhibits neutrophil efferocytosis. Proc Natl Acad Sci USA 2008; 105: 11784-9.

86. Zmijewski JW, Bae HB, Deshane JS, et al. Inhibition of neutrophil apoptosis by PAl-1. Am J Physiol Lung Cell Mol Physiol 2011; 301: L247-54.

87. Di Minno MND, lervolino S, Peluso R, et al. Hemostatic and fibrinolytic changes are related to inflammatory conditions in patients with psoriatic arthritis: effect of different treatments. J Rheumatol 2014; 41: 714-22.

88. Kwon D, Kim JS, Cha BH, et al. The effect of fetal bovine serum (FBS) on efficacy of cellular reprogramming for induced pluripotent stem cell (iPSC) generation. Cell Transplant 2016; 25: 1025-42. 
89. Gv K, Ca M. Serum deprivation induces apoptotic cell death in a subset of Balb/c 3 T3 fibroblasts. I cell Sci 1994; 107: 1169-79.

90. Hayman EG, Ruoslahti E. Distribution of fetal bovine serum fibronectin and endogenous rat cell fibronectin in extracellular matrix. J Cell Biol 1979; 83: 255-9.

91. Cabodevilla AG, Sánchez-Caballero L, Nintou E, et al. Cell survival during complete nutrient deprivation depends on lipid droplet-fueled $\beta$-oxidation of fatty acids. J Biol Chem 2013; 288: 27777-88.

92. Braun F, Bertin-Ciftci J, Gallouet AS, et al. Serum-nutrient starvation induces cell death mediated by Bax and puma that is counteracted by p21 and unmasked by $\mathrm{Bcl}-\mathrm{xL}$ inhibition. PLoS One 2011; 6: e23577.

93. Elmore S. Apoptosis: a review of programmed cell death. Toxicol Pathol 2007; 35: 495-516.

94. Silva MT. Secondary necrosis: the natural outcome of the complete apoptotic program. FEBS Letters 2010; 584: 4491-9.

95. Sachet M, Liang YY, Oehler R. The immune response to secondary necrotic cells. Apoptosis 2017; 22: 1189-204.

96. Rabinovitch M. Professional and non-professional phagocytes: an introduction. Trends Cell Biol 1995; 5: 85-7.

97. Ohata J, Zvaifler NJ, Nishio M, et al. Fibroblast-like synoviocytes of mesenchymal origin express functional B cell-activating factor of the TNF family in response to proinflammatory cytokines. J Immunol 2005; 174: 864-70.

98. Vincent JL, Zambon M. Why do patients who have acute lung injury/acute respiratory distress syndrome die from multiple organ dysfunction syndrome? Implications for management. Clin Chest Med 2006; 27: 725-31.

99. Bartok B, Firestein GS. Fibroblast-like synoviocytes: key effector cells in rheumatoid arthritis. Immunol Rev 2010; 233: 233-55.

100. Cerinic MM, Generini S, Partsch G, et al. Synoviocytes from osteoarthritis and rheumatoid arthritis produce plasminogen activators and plasminogen activator inhibitor- 1 and display u-PA receptors on their surface. Life Sci 1998; 63: 441-53.

101. Juhan-Vague I, Alessi MC, Mavri A, et al. Plasminogen activator inhibitor-1, inflammation, obesity, insulin resistance and vascular risk. J Thromb Haemost 2003; 1: 1575-9.

102. Chan JCY, Duszczyszyn DA, Castellino FJ, et al. Accelerated skin wound healing in plasminogen activator inhibitor1-deficient mice. Am J Pathol 2001; 159: 1681-8.

103. Sternlicht MD, Dunning AM, Moore DH, et al. Prognostic value of PAl1 in invasive breast cancer: evidence that tumor-specific factors are more important than genetic variation in regulating PAl1 expression. Cancer Epidemiol Biomarkers Prev 2006; 15: 2107-14.

104. Wickman GR, Julian L, Mardilovich K, et al. Blebs produced by actin-myosin contraction during apoptosis release damage-associated molecular pattern proteins before secondary necrosis occurs. Cell Death Differ 2013; 20: 1293-305.

105. Bajou K, Peng H, Laug WE, et al. Plasminogen activator inhibitor-1 protects endothelial cells from FasL-mediated apoptosis. Cancer Cell 2008; 14: 324-34.

106. Bonventre JV. Dedifferentiation and proliferation of surviving epithelial cells in acute renal failure. J Am Soc Nephrol 2003; 14 Suppl: S55-61.

107. McMahon BJ, Kwaan HC. Components of the plasminogenplasmin system as biologic markers for cancer. Adv Exp Med Biol 2015; 867: 145-56.

108. Li Y, Cozzi PJ. Targeting UPA/UPAR in prostate cancer. Cancer Treat Rev 2007; 33: 521-7.
109. Pakneshan P, Szyf M, Farias-Eisner R, et al. Reversal of the hypomethylation status of urokinase (UPA) promoter blocks breast cancer growth and metastasis. J Biol Chem 2004; 279: 31735-44.

110. Nykjaer A, Conese M, Christensen El, et al. Recycling of the urokinase receptor upon internalization of the UPA:serpin complexes. EMBO J 1997; 16: 2610-20.

111. Kruidering $M$, van de Water $B$, Zhan $Y$, et al. Cisplatin effects on F-actin and matrix proteins precede renal tubular cell detachment and apoptosis in vitro. Cell Death Differ 1998; 5: 601-14

112. Pasupuleti N, Grodzki AC, Gorin F. Mis-trafficking of endosomal urokinase proteins triggers drug-induced glioma nonapoptotic cell death. Mol Pharmacol 2015; 87: 683-96.

113. Liu HL, Liu D, Ding GR, et al. Hypoxia-inducible factor-1 $\alpha$ and $W n t / \beta$-catenin signaling pathways promote the invasion of hypoxic gastric cancer cells. Mol Med Rep 2015; 12: 3365-73.

114. Bodine PVN. Wnt signaling control of bone cell apoptosis. Cell Res 2008; 18: 248-53.

115. Wyganowska-Świątkowska M, Tarnowski M, Murtagh D, et al. Proteolysis is the most fundamental property of malignancy and its inhibition may be used therapeutically (Review). Int J Mol Med 2019; 43: 15-25. 